\title{
Immunoelectrophoretic Studies on Human Small Intestinal Brush Border Proteins. The Residual Isomaltase in Sucrose Intolerant Patients
}

\author{
HANNE SKOVBJERG ${ }^{1321}$ AND PETER ANDREAS KRASILNIKOFF \\ Department of Biochemistry C. The Panum Institute, Medical-gastroenterological Department C, Herlev Hospital, and \\ Paediatric Department L, Gentofte Hospital, University of Copenhagen, Denmark
}

\begin{abstract}
Summary
Small intestinal biopsies from three patients with sucrose intolerance (sucrase-isomaltase deficiency) were studied by means of immunoelectrophoresis and enzymatic assays. All patients lacked sucrase activity ( $<1$ unit/g protein). One of the patients had a substantial isomaltase activity $(7.8 \mathrm{unit} / \mathrm{g}$ protein). Immunoelectrophoresis revealed the presence of the isomaltase polypeptide of the sucrase-isomaltase in this patient. None of the biopsies showed any precipitate that might represent a modified inactive sucrase protein.
\end{abstract}

\section{Speculation}

It is probable that patients with sucrose intolerance constitute a heterogeneous group, with some of the patients lacking both sucrase and isomaltase activities whereas others have retained an active isomaltase polypeptide.

The sucrase-isomaltase is an integral protein of the small intestinal brush border membrane. It is built up of two distinct polypeptides having either sucrase or isomaltase activity. In sucrose intolerance (sucrase-isomaltase deficiency), failure of sucrose digestion results in abdominal distension and diarrhea.

The molecular background of this disease is not clear. Some studies indicate that the missing enzyme activities are due to lack of the enzyme protein (11,18, 19). In other studies, the findings are compatible with the presence of a catalytically inactive enzyme protein $(8,10)$. Because sucrase and isomaltase activities have a constant ratio in normal biopsies, appear contemporarily during development, and are simultaneously absent in most patients with sucrose intolerance, it has been suggested that they arise from the same structural gene or gene cluster (21). However, some sucrose intolerant patients with a considerable residual isomaltase activity have been described $(3,8-10)$. The molecular background of this phenomenon has not been further investigated.

By crossed immunoelectrophoresis, we recently demonstrated the presence of free isomaltase in addition to the sucrase-isomaltase in normal jejunal biopsies (25). In this paper, we have examined the protein pattern in three sucrose-intolerant patients by immunoelectrophoresis with special emphasis on the molecular background to this disease.

\section{PATIENTS}

Two children ( 2 and 4 years old) and one adult with clinical symptoms of sucrose intolerance were included in the study.

The diagnoses were verified by flat blood glucose curves during sucrose tolerance tests followed by diarrhea. In the children, the sucrose was instilled directly in the duodenum through a tube because false, flat blood glucose curves otherwise easily can be the result (15).
Peroral biopsies were obtained from the small intestine near the ligament of Treitz under fluoroscopic control. The biopsies which were stereomicroscopically normal were frozen $\left(-18^{\circ} \mathrm{C}\right)$ immediately.

\section{MATERIALS AND METHODS}

CHEMICALS

GLOX was obtained from Kabi, Stockholm, Sweden. All other chemicals were obtained as in our previous papers $(24,26)$.

\section{PREPARATION OF ANTISERA}

Brush border membranes were isolated from jejunal biopsies, the proteins were solubilized by Triton X-100, and a polyvalent brush border specific antiserum was raised in rabbits as described earlier (24). To obtain a specific antiserum against sucrase-isomaltase, line immunoelectrophoresis (16) was performed in 0.037 $\mathrm{M}$ sodium barbital buffer, $\mathrm{pH} 8.7$, containing $0.37 \mathrm{M}$ glycine, 0.19 M Tris, $0.1 \%$ Triton X-100, and $0.05 \%$ sodium deoxycholate (24). Three hundred $\mu$ l of the solubilized brush border proteins $(3 \mathrm{mg}$ protein $/ \mathrm{ml}$ ) was electrophorized $(5 \mathrm{~V} / \mathrm{cm}$ for $16 \mathrm{hr}$ ) against the polyvalent antiserum $(2 \mathrm{mg} / \mathrm{ml}$ gel $)$ resulting in several precipitate lines. The precipitates were identified by enzymatic staining (24). The sucrase-isomaltase precipitate was cut, homogenized in $2 \mathrm{ml}$ $0.9 \%$ sodium chloride, mixed with $1 \mathrm{ml}$ incomplete Freund's adjuvant, and used for immunization of a rabbit $(500 \mu \mathrm{l}$ intracutaneously every second wk for $6 \mathrm{wk}$ ). The $\mathrm{IgG}$ fraction was obtained using a Protein A Sepharose column (17).

\section{BIOPSY PREPARATION}

The biopsies were thawed, and the brush border proteins were solubilized with Triton X-100 and quantified in crossed immunoelectrophoresis essentially as described earlier (26). Each biopsy $(9,14$, and $15 \mathrm{mg}$ ) was homogenized in $40 \mu \mathrm{l}$ of a $1 \%$ Triton X-100 solution and incubated for $1 \mathrm{hr}$ at $4^{\circ} \mathrm{C}$. Six $\mu \mathrm{l}$ were removed for enzymatic assays and protein analysis. The rest of the homogenate was centrifuged at $50,000 \times g$ for $1 \mathrm{hr}$, and the supernatant was collected. To solubilize the proteins quantitatively, the pellet was resuspended in $30 \mu \mathrm{l}$ of the Triton X-100 solution, incubated for a further $30 \mathrm{~min}$ at $4^{\circ} \mathrm{C}$, and subsequently centrifuged at 50,000 $\times g$ for $1 \mathrm{hr}$. The two supernatants were pooled. Ten $\mu \mathrm{l}$ of the pooled supernatants were analyzed by rocket immunoelectrophoresis (29) against the specific sucrase-isomaltase antiserum. Another $20 \mu \mathrm{l}$ of the pooled supernatants were mixed with $5 \mu \mathrm{l}$ of a papain solution [papain $(5 \mathrm{mg} / \mathrm{ml})$ and cystein $(1 \mathrm{mg} / \mathrm{ml})$ ] and incubated for $15 \mathrm{~min}$ at $37^{\circ} \mathrm{C}$. Twenty $\mu$ were then analyzed by crossed immunoelectrophoresis against the polyvalent anti-brush border antiserum. After completion of the electrophoresis, the plates were first stained for sucrase, isomaltase, or maltase activity 
using sucrose, palatinose, or maltose as substrates, respectively (24), and then stained for protein by Coomassie brilliant blue.

\section{ENZYMATIC ASSAYS}

The sucrase (EC 3.2.1.48), isomaltase (EC 3.2.1.10), maltase (EC 3.2.1.20), and lactase (EC 3.2.1.23) activities were measured with the Tris/glucose oxidase method according to Dahlqvist (7) using GLOX as a glucose oxidase reagent (1). Sucrose, isomaltose, maltose, and lactose were used as substrates. The activities of microvillus aminopeptidase (EC 3.4.11.2) and dipeptidyl peptidase IV (EC 3.4.14.X) were determined using 1 -alanine-p-nitroanilide and glycyl-L-proline-p-nitroanilide as substrates (24). The enzyme activities were expressed in units, i.e., $\mu$ moles of substrate hydrolyzed per min. The protein concentration was determined according to Wang and Smith (28) using bovine serum albumin as a standard.

\section{RESULTS AND DISCUSSION}

The antiserum obtained by immunizing rabbits with the sucraseisomaltase precipitate was specific against sucrase-isomaltase as judged by immunoelectrophoresis. The solubilization procedure released 90 to $100 \%$ of the studied enzymes (26). Papain was omitted in the solubilization procedure because it might disturb the isomaltase activity in the enzymatic assay $(4,9)$. To improve the quality of the immunoprecipitates, papain was added to the pooled supernatants just before the crossed immunoelectrophoresis (26).

Table 1 shows the specific enzymatic activities of sucrase, isomaltase, lactase, maltase, microvillus aminopeptidase, and dipeptidyl peptidase IV in the biopsies.

The sucrase activity in all the patients were below detection limit of the enzymatic assay ( 1 unit/g protein). Patient 3 showed a substantial isomaltase activity, whereas the activity in the other patients was below detection limit $(0.5$ units/g protein). Because sucrase-isomaltase contributes to about $70 \%$ (14) of the total
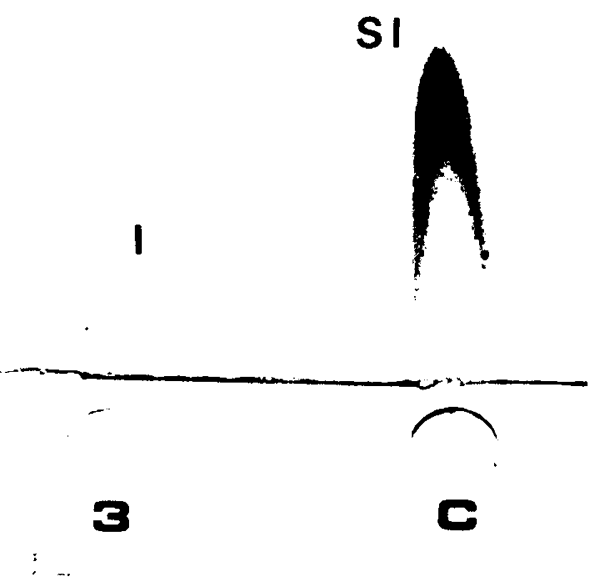

Fig. 2. Rocket immunoelectrophoresis of the biopsy from patient 3 after enzymatic staining with palatinose or maltose (identical pictures). Legend same as in Figure 1.

Table 1. Specific activities against different substrates of intestinal biopsies from the sucrose-intolerant patients and normal controls

\begin{tabular}{|c|c|c|c|c|c|c|c|}
\hline \multirow[b]{2}{*}{ Patient no. } & \multirow[b]{2}{*}{ Age (yr) } & \multicolumn{6}{|c|}{ Units/g protein } \\
\hline & & Sucrose & Isomaltose & Maltose & Lactose & $\begin{array}{l}\text { L-Alanine-p-ni- } \\
\text { troanilide }\end{array}$ & $\begin{array}{l}\text { Glycyl-L-proline-p-ni- } \\
\text { troanilide }\end{array}$ \\
\hline 1 & 37 & $<1$ & $<0.5$ & 46.7 & 79.5 & 58.9 & 19.1 \\
\hline 2 & 2 & $<1$ & $<0.5$ & 32.3 & 58.9 & 126.5 & 22.7 \\
\hline 3 & 4 & $<1$ & 7.8 & 64.6 & 35.0 & 53.4 & 20.2 \\
\hline Normal range & & $46-92$ & $36-93^{2}$ & $129-300$ & $18-45$ & $52-128$ & $15-34$ \\
\hline
\end{tabular}

'The normal ranges were obtained from 11 jejunal biopsies described earlier (23).

" The values were obtained from Asp et al. (2).



Fig. 1. Rocket immunoelectrophoresis after staining with Coomassie brilliant blue. The biopsies were solubilized as described in "Materials and Methods" and electrophoresed against the specific sucrase-isomaltase an-

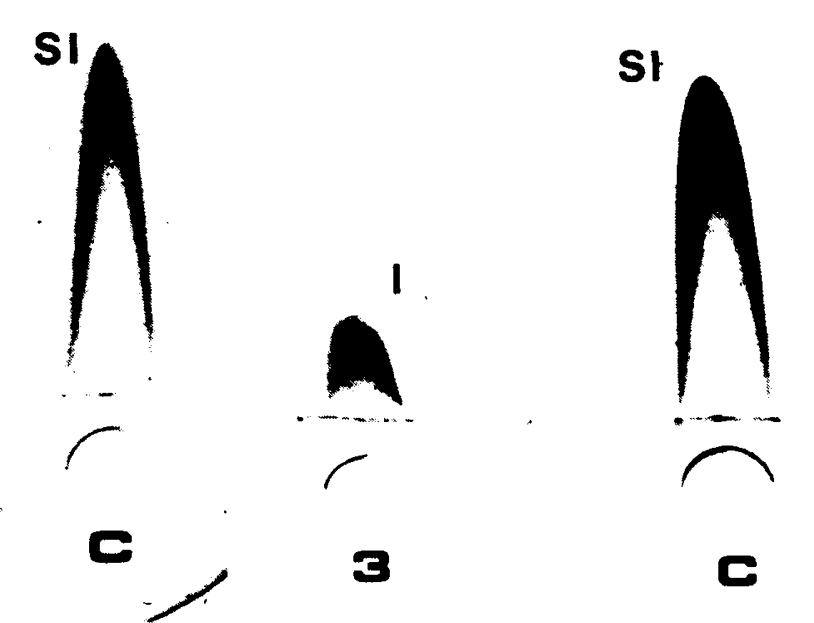

tiserum $\left(60 \mu \mathrm{g} \mathrm{IgG} \mathrm{per} \mathrm{cm}^{2}\right)$. As control, a normal biopsy was electrophoresed simultaneously with each of the sucrase-deficient biopsies. Number. patient number; $C$, control biopsy; $S I$, sucrase-isomaltase; $I$, isomaltase. 

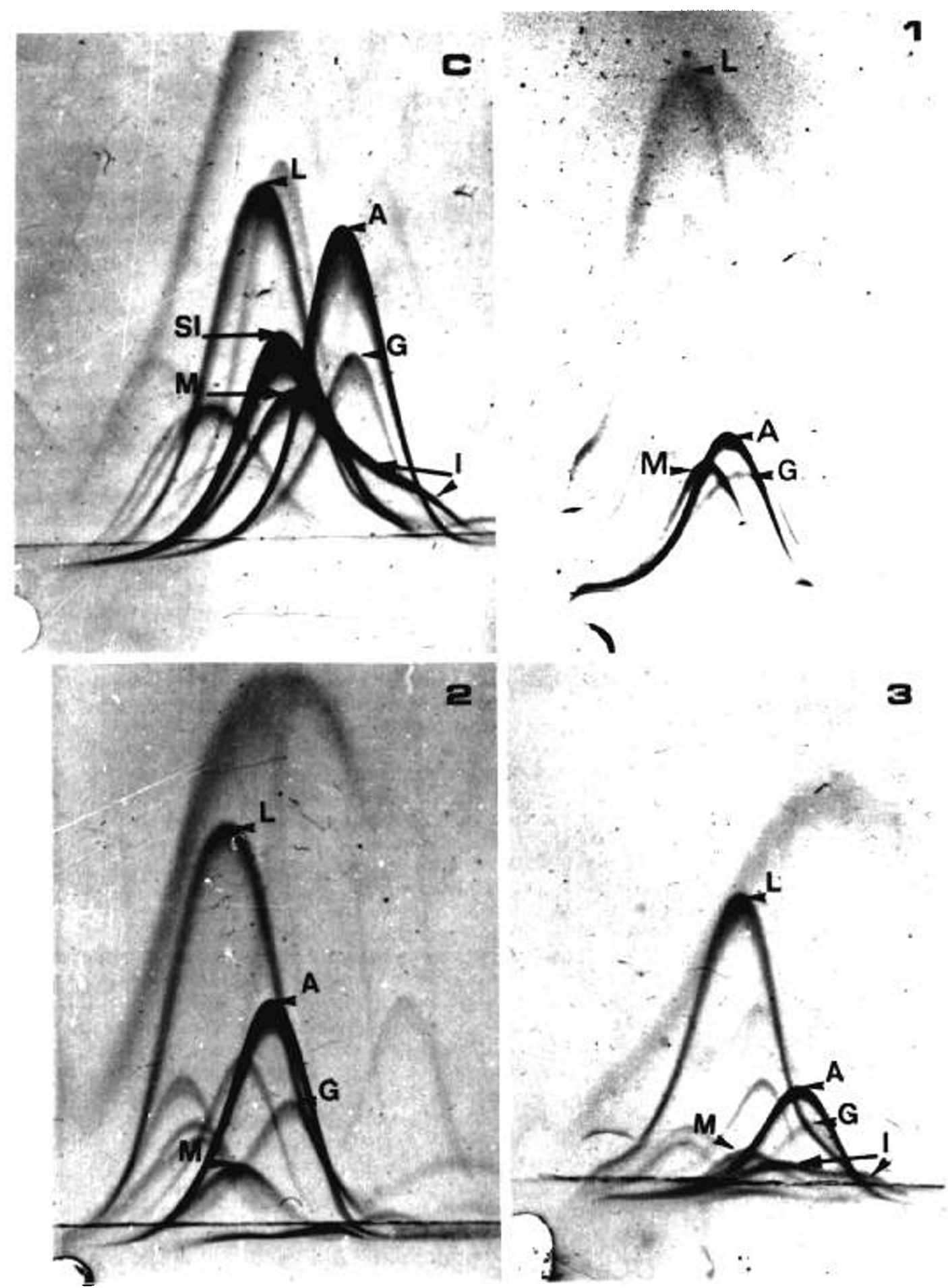

Fig. 3. Crossed immunoelectrophoresis of small intestinal biopsies after staining with Coomassie brilliant blue. Number, patient number. The antibody concentration was $30 \mu \mathrm{g} / \mathrm{cm}^{2}$ gel. $C$, control biopsy; $S I$, sucrase

maltase activity in normal biopsies, this activity was low in our patients whereas the activity of the other enzymes were within normal limits.

Rocket immunoelectrophoresis (Fig. 1) of a normal biopsy against the specific sucrase-isomaltase antiserum reveals one single precipitate which by enzymatic staining had sucrase, isomaltase, and maltase activities. The biopsies from patients 1 and 2 show no precipitates. Thus, no immunological reactive, enzymatic inactive sucrase-isomaltase was detected, In contrast, the biopsy from patient 3 shows one precipitate. By enzymatic staining (Fig. 2), this precipitate had isomaltase and maltase activities, but no isomaltase: $I$, isomaltase: $M$, maltase: $L$. lactase-phlorizin hydrolase: $A$, microvillus aminopeptidase; $G$, dipeptidyl peptidase IV

sucrase activity. This enzymatic staining pattern together with the precipitation with the specific sucrase-isomaltase antiserum suggests that the precipitate represents the free isomaltase polypeptide of the sucrase-isomaltase.

In crossed immunoelectrophoresis (Fig. 3) against the polyvalent brush border antiserum, the three biopsies show normal maltase, lactase, microvillus aminopeptidase, and dipeptidyl peptidase IV precipitates compared to a normal biopsy. As previously shown (25), normal jejunal biopsies contain a small amount of free isomaltase that in crossed immunoelectrophoresis interferes with the sucrase-isomaltase precipitate. The biopsy from patient 
3 shows in crossed immunoelectrophoresis one precipitate (I) with a similar electrophoretic mobility and the same enzymatic staining properties as the free isomaltase precipitate in the normal biopsies (Fig. 3). This indicates that the free isomaltase polypeptide in patient 3 has the same electrophoretic mobility as in normal biopsies. It has been suggested (10) that the isomaltase in sucrasedeficient patients might aggregate with maltase. This seems on background of the crossed immunoelectrophoretic pattern not to be the case in patient 3 because the isomaltase precipitate and the maltase precipitate are separated from each other. Also, the maltase precipitate has the same electrophoretic mobility as in normal biopsies.

The molecular background of sucrose intolerance has been studied with various methods during the last years. Preiser $e t$ al. (18) and Schmitz et al. (19) noted the absence of protein bands in the sucrase-isomaltase position in polyacrylamide gels of four sucrose-intolerant patients. This result was supported by Gray et al. (11) using radioimmunoassays on biopsies from seven sucroseintolerant patients. In contrast, Dubs et al. (8) and Freiburghaus et al. (10) demonstrated by immunohistochemical means, using specific antibodies against the sucrase-isomaltase complex, crossreacting protein in sucrose-intolerant patients suggesting that it represented an inactive enzyme variant. Although different experimental approaches might account for the discrepancies in the mentioned studies, there seems to be some correlation between the residual isomaltase activity and the reported findings. In the patients studied by Dubs et al. (8), the immunofluorescence varied greatly, but the most intensive staining occurred in three patients with a high residual isomaltase activity. Also, the patient studied by Freiburghaus et al. (10) had a high isomaltase activity. In contrast, the patients studied by Preiser et al. (18), Schmitz et al. (19), and Gray et al. (11) were reported to have undetectable isomaltase activity.

The antibodies used by Dubs et al. (8) and Freiburghaus et al. (10) were raised against sucrase-isomaltase. Because our study demonstrates the presence of the isomaltase polypeptide in the patient with isomaltase activity, we suggest that the immunofluorescence obtained in the two studies might be caused by the presence of the isomaltase enzyme and not by an inactive sucrase enzyme. Furthermore, we have not in our study found any crossreacting inactive enzyme variant.

Studies on rat and pig intestinal sucrase-isomaltase $(13,22)$ indicate that the enzyme is synthesized as one-polypeptide chain. The demonstration of free isomaltase might point to the possibility that the two enzymes are synthesized separately. On the other hand, assuming a one-polypeptide chain synthesis, several genetic mechanisms might explain why some sucrase-deficient patients still synthesize isomaltase. Various alterations in the structural gene might lead to synthesis of only the isomaltase part of the polypeptide or to synthesis of a defect sucrase part of the enzyme that is more easily degraded than the isomaltase part. The existence of free isomaltase is in fact compatible with the hypothesis that the synthesis of sucrase-isomaltase starts with the N-terminal isomaltase peptide, also responsible for the insertion of the enzyme in the membrane (6).

As judged from the literature $(3,5,8-12,18,19)$ approximately $20 \%$ of the described sucrose-intolerant patients have. like patient 3 in our study, a considerable isomaltase activity ( 10 to $25 \%$ of the normal mean value). The activity seems, however, always depressed compared to normal biopsies which means that also the synthesis of isomaltase is affected or that isomaltase is more easily degraded when not associated with sucrase. Whether the residual isomaltase polypeptide has the same molecular weight as the normal isomaltase subunit remains to be settled. On background of polyacrylamide gel electrophoresis, it has been suggested that it might occur as an aggregated high-molecular-weight complex (10). Another possibility is that it is synthesized as a high-molecular-weight, one-polypeptide chain isomaltase as is the case in the sea lion (27).

It is possible that the sucrose-intolerant patients constitute a heterogeneous group with more or less affection of the structural gene responsible for the synthesis of sucrase-isomaltase. Because the immunoelectrophoretic technique also measures possible immunoreactive intracellularly localized sucrase-isomaltase molecules, it seems unlikely that the disease is caused by a defect incorporation of the enzymes in the membrane as has been suggested (20).

\section{REFERENCES AND NOTES}

I. Asp, N. G.: (personal communication).

2. Asp. N. G., Gudmand-Høyer, E., Andersen. B.. Berg. N. O., and Dahlqvist, A.: Distribution of disaccharidases. alkaline phosphatase and some intracellular enzymes along the human small intestine. Scand. J. Gastroenterol., 10: 647 (1975).

3. Auricchio, S., Ciccimarra, F., Moauro, L., Rey, F., Jos. J., and Rey. J.: Intraluminal and mucosal starch digestion in congenital deficiency of intestinal sucrase and isomaltase activities. Pediatr. Res., 6: 832 (1972).

4. Auricchio, S., Dahlquist. A., and Semenza, G.: Solubilization of the human intestinal disaccharidases. Biochim. Biophys. Acta, 73: 582 (1963).

5. Auricchio, S.. Rubino, A., Prader. A.. Rey. J.. Jos, J.. Frézal, J., and Davidson. M.: Intestinal glycosidase activities in congenital malabsorption of disaccharides. J. Pediatr., 66: 555 (1965).

6. Brunner, J., Hauser, H., Braun. H., Wilson. K. J., Wacker, H., O'Neill, B., and Semenza. G.: The mode of association of the enzyme complex sucrase-isomaltase with the intestinal brush border membrane. J. Biol. Chem., 254: 1821 (1979).

7. Dahlquist, A.: Assay of intestinal disaccharidases. Anal. Biochem., 22: 99 (1968).

8. Dubs, R., Steinmann, B., and Gitzelmann. R.: Demonstration of an inactive enzyme antigen in sucrase-isomaltase deficiency. Helv. Paediatr. Acta. 28: 187 (1973).

9. Eggermont, E., and Hers, H. G.: The sedimentation properties of the intestinal a-glucosidases of normal human subjects and of patients with sucrose intolerance. Eur. J. Biochem., 9: 488 (1969).

10. Freiburghaus, A. U.. Dubs, R.. Hadorn, B., Gaze. H., Hauri. H. P., and Gitzelmann, R.: The brush border membrane in hereditary sucrase-isomaltase deficiency: Abnormal protein pattern and presence of immunoreactive enzyme. Eur. J. Clin. Invest.. 7: 455 (1977).

11. Gray, G. M., Conklin, K. A., and Townley, R. R. W.: Sucrase-isomaltase deficiency. Absence of an inactive enzyme variant. N. Engl. J. Med., 294: 750 (1976).

12. Greene, H. L., Stifel, F. B., and Herman, R. H.: Dietary stimulation of sucrase in a patient with sucrase-isomaltase deficiency. Biochem. Med.. o: 409 (1972).

13. Hauri, H. P.. Quaroni, A.. and Isselbacher. K. J.: Biogenesis of the intestinal plasma membrane: posttranslational route and cleavage of sucrase-isomaltase Proc. Natl. Acad. Sci.. 76: 5183 (1979).

14. Kelly, J. J., and Alpers. D. H.: Properties of human intestinal glucoamylase. Biochim. Biophys. Acta, 315: 113 (1973).

15. Krasilnikoff. P. A.. Gudmand-Høyer, E.. and Moltke. H. H.: Diagnostic value of disaccharide tolerance tests in children. Acta Paediatr. Scand., 04: 693 (1975)

16. Krøll. J.: Line Immunoelectrophoresis. In: N. H. Axelsen, B. Weeke: A Manual of Quantitative Immunoelectrophoresis. Methods and Applications. pp. 61-67 (Universitetsforlaget, Oslo, 1973).

17. Norén, O.. and Sjoström. H.: The insertion of pig microvillus aminopeptidase into the membrane as probed by $\left[{ }^{\mid 2 ! I} I\right]$ iodonaphthylazide. Eur. J. Biochem.. 104: 25 (1980).

18. Preiser. H., Menard. D., Crane, R. K., and Cerda. J. J.: Deletion of enzyme protein from the brush border membrane in sucrase-isomaltase deficiency. Biochim. Biophys. Acta, 363: 279 (1974).

19. Schmitz. J.. Commegrain, C.. Maestracci, D.. and Rey. J.: Absence of brush border sucrase-isomaltase complex in congenital sucrose intolerance. Biomedicine (Paris), 2I: 440 (1974).

20. Schmitz, J., and Rey. J.: Congenital sucrose intolerance: further studies at the molecular level. Gastroenterol. Clin. Biol., 2: 329 (1978).

21. Semenza, $G$.: The mode of anchoring of sucrase-isomaltase to the small intestinal brush border membrane and its biosynthetic implications. Processing and turnover of proteins and organelles in the cell. In: S. Rapaport. T. Scheve: Symp. 12th FEBS Meet., Dresden, July 2-8. 1978. Vol. 53, pp. 21-28 (Pergamon Press, London. 1978)

22. Sjostrom, 11., Noren, O., Christiansen, L.. Wacker, 11., and Semenza, (j.. A lully active two-active site. single chain sucrase-isomaltase from pig small intestine. Implications for the biosynthesis of a mammalian integral stalked membrane protein. J. Biol. Chem.. 25.5: 11332 (1980).

23. Skovbjerg. H.. Gudmand-Hoyer, E., and Fenger. H. J.: Immunoelectrophoretic studies on human small intestinal brush border proteins. The amount of lactase protein in adult type hypolactasia. Gut, $21: 360$ (1980).

24. Skovbjerg. H., Norén, O., and Sjöstrom, H.: Immunoelectrophoretic studies on human small intestinal brush border proteins. A qualitative study of the protein composition. Scand. J. Clin. Lab. Invest.. 38: 723 (1978)

25. Skovbjerg. H., Sjostrom, H., and Norén. O.: Does sucrase-isomaltase always exist as a complex in human intestine? FEBS Lett.. 108: 399 (1979).

26. Skovbjerg, H., Sjöström. H., Norén, O., and Gudmand-Høyer. E.: Immunoelectrophoretic studies on human small intestinal brush border proteins. A quantitative study of brush border enzymes from single small intestinal biopsies. Clin. Chim. Acta. 92: 315 (1979).

27. Wacker. H.. Aggeler, R., Burell. K.. Kretchmer, N.. Takesue, Y., and Semenza G.: A single-chain, two-active-sites enzyme: The isomaltase from sea lion small 
intestinal brush border membrane. Its possible philogenetic relation with sucrase-isomaltase. In preparation.

28. Wang, C. S., and Smith. R. L.: Lowry determination of protein in the presence of Triton X-100. Anal. Biochem. 6.3: 414 (1975).

29. Weeke, B.: Rocket Immunoelectrophoresis. In: N. H. Axelsen. B. Weeke: A Manual of Quantitative Immunoelectrophoresis. Methods and Applications. pp. 37-46 (Universitetsforlaget, Oslo, 1973).

30. The authors thank Drs. H. Sjoström, O. Norén, and E. Gudmand-Høyer for helpful discussions.
31. The authors are grateful to $D$. Anthonsen for excellent technical assistance.

32. Requests for reprints should be addressed to: Hanne Skovbjerg, Department of Biochemistry C. The Panum Institute. Blegdamsvej 3. DK-2200 Copenhagen N. Denmark.

33. This research was supported by the Danish Medical Research Council (No. 512 10175). P. Carl Petersens Fond (No. B 1076), and the Novo Foundation.

34. Received for publication June 18, 1980.

35. Accepted for publication July 22, 1980. 